\title{
ArcheoSciences
}

Revue d'archéométrie

33 (suppl.) | 2009

Mémoire du sol, espace des hommes

\section{Batilly-en-Gâtinais (Loiret), a rural aristocratic settlement}

S. Fichtl, Michel Dabas and K. Gruel

\section{(2) OpenEdition \\ 1 Journals}

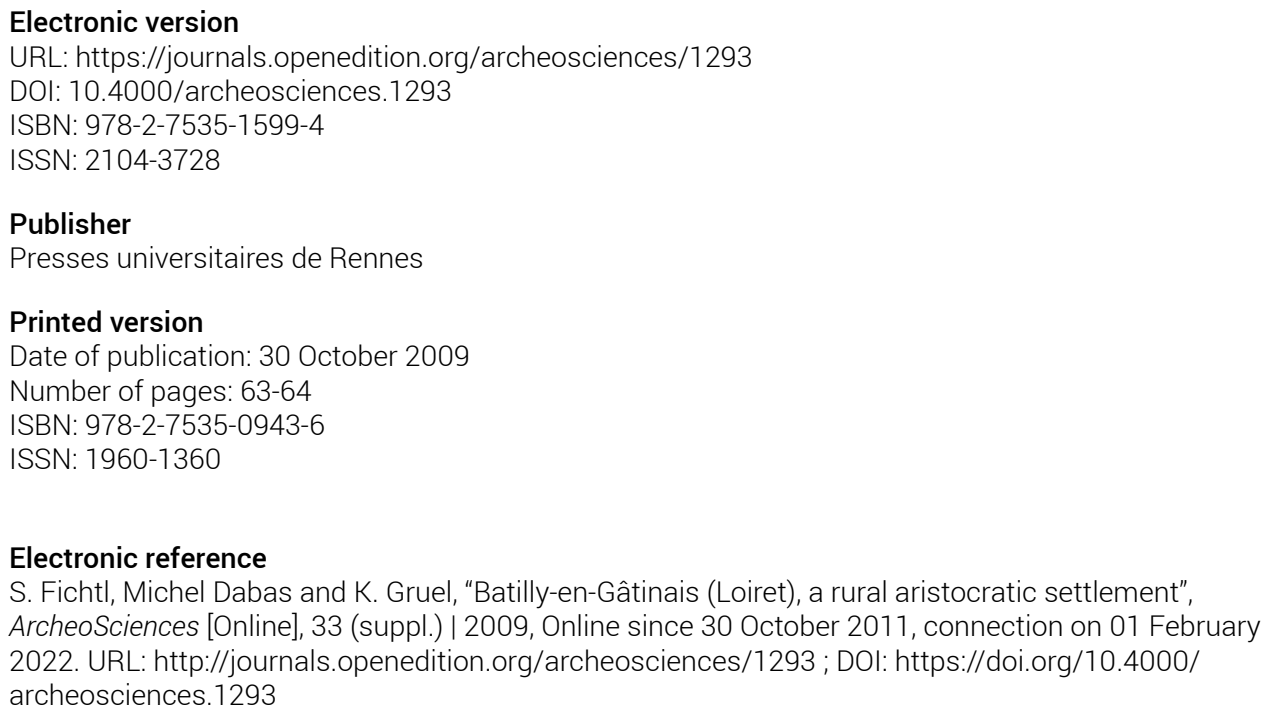




\title{
Batilly-en-Gâtinais (Loiret), a rural aristocratic settlement
}

\author{
S. FichtL *, M. Dabas ** and K. Gruel *
}

Key words: Iron Age, Magnetic survey, Rural settlement, Aristocracy, Aerial photography.

The site of "Pierriers" at Batilly-en-Gatinais (France) was first located in aerial photographs (Dominique Chesnoy) taken at the beginning of 2000. Archaeological testing by René Chemin from INRAP was carried out in 2005 during the construction of the A19 motorway. Excavation followed between July 2006 and March 2007 under the direction of Sophie Liegard (INRAP, site I\& 1-2). Concurrently, Terra NovA (now GEOCARTA sa.) undertook magnetic surveys to the north and south of the main enclosure within the framework of the ANR Celtecophys project. Liegard's work brought the first interpretation of this site as a rural settlement of aristocratic origin, dating from the end of the Gallic period.

The site is composed of a rectangular enclosure 150 by $120 \mathrm{~m}$, delimited by a $6.5 \mathrm{~m}$ broad ditch of a depth of $3.5 \mathrm{~m}$. This enclosure is characterized by a regular subdivision of space into four zones about $30 \mathrm{~m}$ wide, marked by cobbed and painted palisades. Passage between zones was via a tower-porch resting on 12 posts. The main enclosure was entered through a monumental tower-porch with four known phases of construction. Several buildings were excavated, all of them having complex plans and built for the most part on posts sunk in foundation trenches.

The enclosure lies at the extremity of a bigger one measuring at least 370 by $250 \mathrm{~m}$. At the forefront, there is a vast esplanade, 170 by $150 \mathrm{~m}$, surrounded by several buildings intended for storage or linked to craftwork. At the rear of

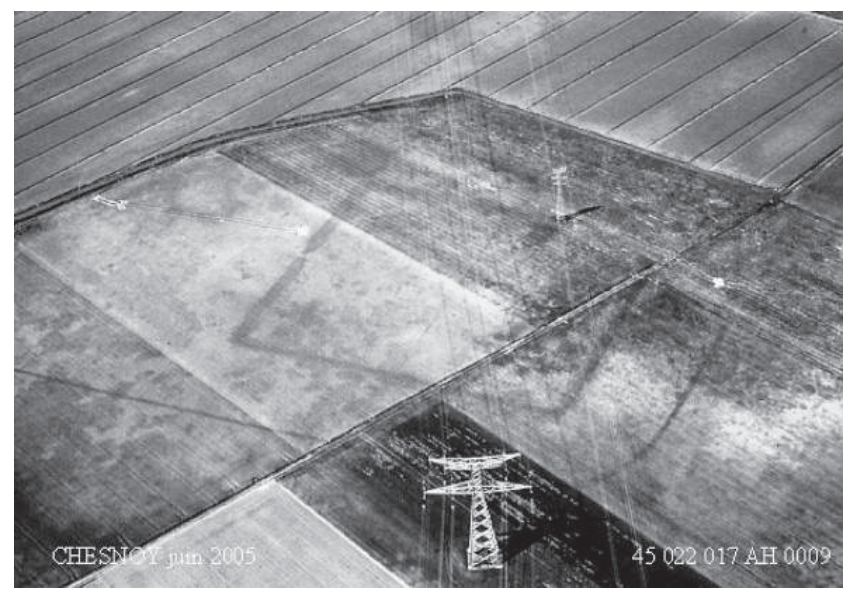

Figure 1: Aerial photo of the rural settlement of Batilly-en-Gâtinais, Loiret (photo D. Chesnoy)

this second enclosure, five burial places (in sitting position) were found; several other burial places were also recorded by magnetic surveys carried out to the north of the excavations.

In his work on the Gallic peasants François Malrain proposed a hierarchy of rural settlements, according to which this site corresponds to the highest category:

- space divided into two clearly defined sectors as pars urbana (central enclosure) and pars rustica with buildings surrounding an esplanade;

*CNRS/ENS, UMR AOROC CNRS/ENS-Paris, Univ. de Tours. (stephan.fichtl@univ-tours.fr)

**GEOCARTA, Paris. (dabas@geocarta.net) 
Figure 2: Magnetic map (from -2 to $2 \mathrm{nT}$, horizontal scale $100 \mathrm{~m}$ )

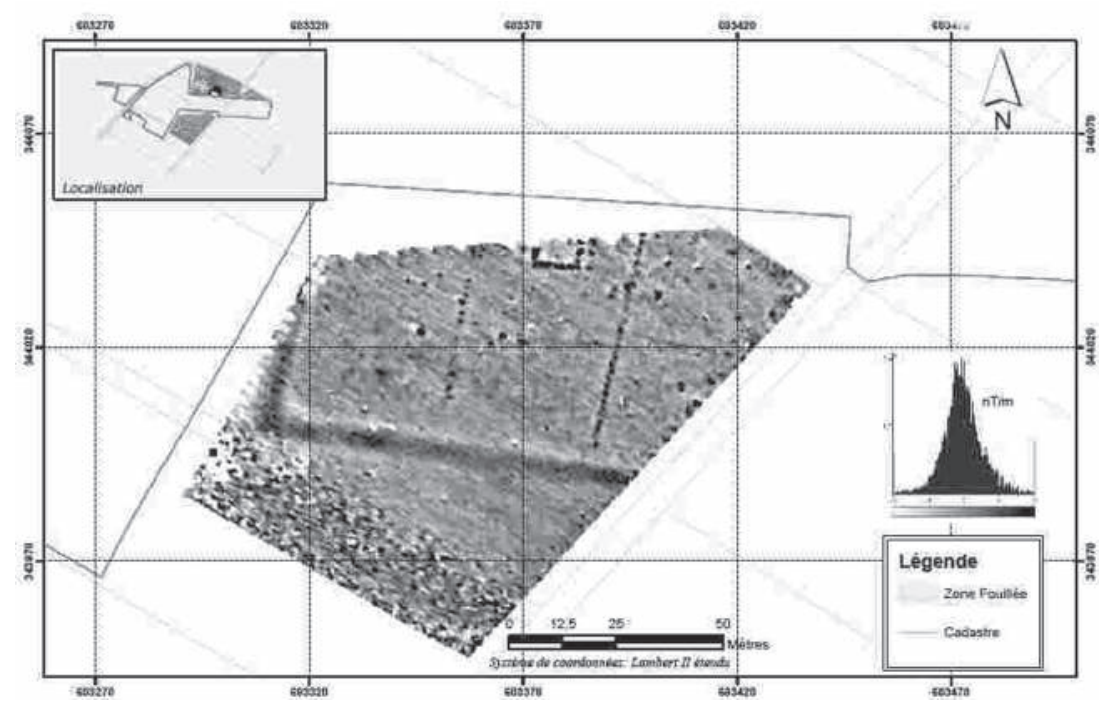

- clear symmetry of the site with regular space organisation;

- several, probably at least twelve burial places (in sitting position) indicating a cultic area;

- floral decoration on cobbed walls, probably in buildings and on palisades; one of the colors corresponds to Egyptian blue and may be considered as a Mediterranean importation;

- important share of imported material, with an NMI of more than 400 amphoras;

- presence of weapons;

- small bronze figurine representing a bird of prey, of a quality indicative of the aristocratic sphere.

These high quality artifacts are remarkable despite the absence of structures like pits and silos. Only $28 \%$ of the overall length was covered by the trench $(150 \mathrm{~m}$ out of $540 \mathrm{~m}$ ).

The site was occupied between the middle of the 2nd century and the middle of the 1 st century BC (LT D1 and LT D2a) with a reoccupation phase in the Augustan period. It is not clear what happened in the hiatus and whether the site continued to be occupied during this period.

Rescue archaeological excavation could study only the smaller half of the 10 ha site (surface estimated inside the enclosure), not being able thus to give a full image of this aristocratic settlement. With a site of such dimensions, excavations could not be made randomly, but had to rely on a global understanding of the settlement drawing from aerial photos and magnetic mapping. Sectors for excavation could be chosen on these grounds, addressing specific archaeological issues and adapting the methodology accordingly: excavating a necropolis requires different techniques than digging a trench $7 \mathrm{~m}$ wide!

The 2008 archaeological campaign conducted by the University F. Rabelais (Tours) made use of the new data. Their trench was located inside the main enclosure, near the already excavated area, based on aerial photos and the results of a geomagnetic survey carried out by Terra Nova in 2007. These two documents showed the continuity of the palisades, already recognized previously, and a large building with post holes visible in the geomagnetic survey as well as on aerial photographs.

Batilly-en-Gâtinais is thus a good example of the use of combined surveying techniques for understanding a site of such an extent that completing its excavation would require a multi-year research program.

\section{References}

LIÉGARD, S., 2005-2006. Batilly-en-Gâtinais, "Les Pierrière ". Revue Archéologique du Loiret, 30-31: 98-99.

LIÉGART, S., 2007A. L'habitat aristocratique de Batilly-en-Gâtinay (Loiret). Bulletin de l'AFEAF, 25: 51-52.

LiÉGARD, S., 2007в. Les Pierrières à Batilly-en-Gâtinais (Loiret). Archéopages, 19.

Malrain, F., Matterne, V. and Méniel, P., 2002. Les Paysans gaulois (III siècle-52 av. J.-C.). Paris: Errance.

This geophysical survey has been financed partly by the ANR CELTECOPHYS program. 